\title{
INVESTIGATING THE TRENDS OF AVERAGE COSTS OF CORRECTIVE MAINTENANCE OF PUBLIC TRANSPORT VEHICLES
}

\section{BADANIE TENDENCJI PRZECIECTNYCH KOSZTÓW NIEPLANOWEJ OBSLUGI POJAZDÓW TRANSPORTU MASOWEGO}

\author{
Karol Andrzejczak, Jarosław Selech \\ Poznan University of Technology \\ Politechnika Poznańska
}

\begin{abstract}
This paper presents the results of the investigations of the trends of average costs incurred by manufacturers of public transport vehicles following the elimination of unplanned malfunctions under warranty. The developed research methodology utilizes a method of analysis of variance for validation of the following two hypotheses. The first hypothesis relates to the examination of the significance of differences between average costs of the elimination of a malfunction and the other relates to the examination of the significance of differences in the average number of malfunctions per single vehicle in the highlighted periods of operation. The hypotheses were conducted based on the operation data relating to the malfunctions of a fleet of trams used by a city transport operator.
\end{abstract}

Keywords: public transport, corrective maintenance, maintenance cost

Streszczenie: Niniejsza publikacja poświęcona jest przedstawieniu wyników badań tendencji przeciętnych kosztów ponoszonych przez producenta środków transportu masowego z tytulu usuwania uszkodzen nieplanowych $w$ okresie gwarancyjnym. Wopracowanej metodzie badawczej zastosowano analize wariancji do zweryfikowania dwóch hipotez. Pierwsza hipoteza dotyczy zbadania istotności różnic przeciętnych kosztów usuwania uszkodzeń, a druga hipoteza dotyczy zbadania istotności różnic przeciętnej liczby uszkodzeń przypadających na jeden pojazd $w$ wyróżnionych okresach ich użytkowania. Weryfikacji tychi̇e hipotez dokonano na podstawie danych eksploatacyjnych dotyczacych uszkodzeń floty tramwajów eksploatowanych przez miejskie przedsiębiorstwo komunikacyjne.

Slowa kluczowe: transport publiczny, naprawa nieplanowa, koszt obstugi 
Investigating the trends of average costs of corrective maintenance of public... Badanie tendencji przeciętnych kosztów nieplanowej obstugi pojazdów...

\section{INVESTIGATING THE TRENDS OF AVERAGE COSTS OF CORRECTIVE MAINTENANCE OF PUBLIC TRANSPORT VEHICLES}

\section{Introduction}

The analysis of costs of maintenance of means of public transport is rather complicated, which is confirmed by numerous works addressing this problem (see [6], [8], [12], [7]). Except the cost of purchase, the main cost-generating factor in the case of a fleet of public transport vehicles includes the costs incurred in the stage of operation. The costs generated at this stage of vehicle life cycle are analyzed in detail from the point of view of the fleet supplier and (most likely a manufacturer) and from the point of view of the end-user understood as a public transport operator. A manufacturer (supplier) of the fleet is interested in the costs of the stage of operation, as he absorbs the costs of warranty and service contracts at the initial stage of the vehicle operation. Knowing the costs of operation allows the supplier to increase his sale competitive advantage as well as boost the bidding potential, let alone additional financial benefits. However, knowing the costs of operation, the operator can control them, thus decreasing the financial risk connected with planned and preventive as well as forced (corrective) maintenance of vehicles, significantly limits the risk of fleet availability and decreases the risk related to safety of transport activities. Additionally, knowing the forecasted costs of operation at the very stage of selection of the fleet supplier, the operator can evaluate the efficiency of alternative solutions (see [4], [5]).

Designers, manufacturers and end-users of means of transport attempt to minimize the possible occurrence of various undesired events during fleet operation. In order to minimize the malfunction elimination costs, a designer has to know the cause and types of undesired events that may occur in operation. This allows preventing such events or makes the equipment resistant to effects of such events by designing various types of redundant systems and arrangement of preventive activities that minimize the costs of fleet operation (see [2], [6], [14]). Despite the fact that already at the stage of design, requirements relating, among others, to assumed fleet operating readiness are considered, it is impossible to avoid incidental malfunctions of vehicles during the period of their operation, which generates unplanned costs of operation. In order to design and build complex technical equipment fulfilling the requirements related to energy consumption, ecology, safety, readiness and functionality, comprehensive detailed knowledge is necessary regarding, among others, predicting how often and when undesired events may occur in operation (see [3] [11], [13]). In this paper, the authors present the results of research on unplanned costs of warranty malfunction repair as conducted based on the data relating to a fleet of trams used by a city transport operator. 
The paper includes five parts and literature references. Part 2 specifies the discussed problem of cost-generation of the operation of a fleet of public transport vehicles. Part 3 presents the research problem and the research methodology. Part 4 presents the results of the research on the example of a fleet of public transport vehicles. The paper ends with conclusions and literature references.

\section{Specification of the problem of costs generation}

Direct costs of operation of a fleet of vehicles include the costs of use, i.e. the costs generated during operation of a vehicle (costs of energy, materials and operators), costs of planned maintenance (e.g. costs of proactive works, i.e. inspections and repairs, spare parts, adjustment and maintenance) as well as costs of corrective maintenance forced by incidental events and including, among others, the costs of vehicle roadworthiness (e.g. adjustment of screws, fastenings and electrical connections, change of settings and resetting of electronic devices, renewal of damaged glazing, road accident repairs, costs of penalties caused by the fact that the vehicle was not roadworthy etc.) or detected during planned maintenance as a preventive activity.

In order to make a detailed analysis of the costs of the stage of operation of a fleet of public transport vehicles, including a possible attempt to provide a forecast of cost types, all cost-generating events have to be recorded. Creation of a database of the widely understood malfunction trend, considering all costs of operation of a fleet in public transport, belongs to the fundamental activities in the process of planning of costs, service and renovation (see [6]).

The database relative to malfunction trend and costs of operation and service can be obtained from the operating documentation of a fleet of public transport vehicles such as trams used by a large transport operator. Using the database, it is possible to identify the most cost-generating parts (see [1]), estimate the unit costs and determine the characteristics of reliability necessary in the planning of further fleet operation.

\section{The research problem and method}

The research problem relates to a comparative analysis of average costs of elimination of incidental malfunctions and their number in selected periods of operation of a fleet of identical public transport vehicles. Due to a possible introduction of new vehicles included in the tested fleet at times, the selected periods of use of the vehicles will be expressed in vehicle mileage [in $\mathrm{km}$ ]. The calculation of the periods of use of vehicles using their mileages allows a better analysis of the costs of elimination of malfunctions and moments of occurrence of the same with diversified intensity of vehicle operation.

In this paper the analysis of costs is confined to the costs not included in planned inspections. Therefore, this is an analysis of costs of part renewal (parts damaged incidentally during operation, usually between inspections). The analysis of costs is made based on properly prepared operating databases related to the tested fleet of vehicles. 
Investigating the trends of average costs of corrective maintenance of public... Badanie tendencji przeciętnych kosztów nieplanowej obstugi pojazdów...

The information included in the database determines the scope of tests in operation. The basic data of the source database include, among others, the information related to:

- ordinal number of the part mentioned in chronology of events,

- vehicle marking,

- spare part index,

- structural group,

- vehicle mileage, at which malfunction occurred,

- name of renewed part,

- repair date,

- costs of parts,

- costs of labor.

Examples of records are presented in table 1.

Table 1. The structure of the source database

\begin{tabular}{|c|c|c|c|c|c|c|c|}
\hline Part & Part index & $\begin{array}{c}\text { Structural } \\
\text { group }\end{array}$ & $\begin{array}{c}\text { Mileage } \\
{[\mathbf{k m}]}\end{array}$ & Part name & $\begin{array}{c}\text { Repair } \\
\text { date }\end{array}$ & $\begin{array}{c}\text { Cost of } \\
\text { part } \\
{[\text { PLN] }}\end{array}$ & $\begin{array}{c}\text { Costs of } \\
\text { man- } \\
\text { hours } \\
{[\text { PLN] }}\end{array}$ \\
\hline 1. & $0004-010-219$ & 8 & 196006 & $\begin{array}{c}\text { Pressure } \\
\text { sensor }\end{array}$ & $2015-06-15$ & 488.67 & 330.00 \\
\hline 2. & $3400-003-454$ & 24 & 125588 & $\begin{array}{c}\text { Door } \\
\text { controller }\end{array}$ & $2013-04-24$ & 29333.88 & 660.00 \\
\hline 3. & $3400-003-574$ & 8 & 196006 & $\begin{array}{c}\text { Horizontal } \\
\text { shock } \\
\text { absorber }\end{array}$ & $2013-10-16$ & 1286.00 & 220.00 \\
\hline
\end{tabular}

In the tests on the relevance of differences between the average costs of elimination of incidental malfunctions, data related to the mileage of vehicles were used, at which a given malfunction occurred as well as data related to part indexes, part costs and costs of labor connected with the elimination of individual malfunctions. The presented tests considered the total costs of elimination of the malfunction, part costs and costs of man-hours (in Polish - RBG) connected with the part renewal.

Let us assume that $B_{(0 ; L)}$ denotes a database with operating data for the period of introduction of individual vehicles to the use until reaching a mileage of $L[\mathrm{~km}]$ by all vehicles included in the fleet. Using the database of $B_{(0 ; L)}$ with costs of elimination of incidental malfunctions to the fleet vehicles that reached the mileage of at least $L[\mathrm{~km}]$, tests are carried out on the relevance of differences between the average costs of malfunction elimination in the selected $k$ periods of vehicle mileage. Therefore, mileage $L$ expressed in $[\mathrm{km}]$ for each vehicle of the fleet is divided into $k$ equal mileage periods, i.e. we divide $L$ mileage into intervals (1)

$$
\left[0 ; \frac{1}{k} L\right),\left[\frac{1}{k} L ; \frac{2}{k} L\right), \ldots,\left[\frac{k-1}{k} L ; L\right)
$$


Consequently, from $B_{(0 ; L)}$ database relating to the fleet of $N$ vehicles, we create $k$ sub-databases $B_{1}, B_{2}, \ldots, B_{k}$ connected with the selected periods of vehicle operation. The data have been used to test the hypothesis of whether there are significant differences between the average costs of malfunction elimination during the selected periods of vehicle mileage. Therefore, a null hypothesis (2) is tested

$$
H_{0}: \mu_{1}=\mu_{2}=\cdots=\mu_{k}
$$

where $\mu_{i}$ means the average level of costs of elimination of incidental malfunctions of vehicle in an $i$-th period of use. Rejection of the null hypothesis means that there are certain trends. Before resolving this problem, a result of verification of the hypothesis will be presented: a random number of recorded malfunctions per fleet vehicle does not differ significantly from individual mileage periods of the vehicles. This null hypothesis takes the following form:

$$
H_{0}: u_{1}=u_{2}=\cdots=u_{k}=u_{0}
$$

where $u_{i}$ means the average number of malfunctions per fleet vehicle in an $i$-th mileage period $(i=1,2, \ldots, k)$, whereas $u_{0}$ is an a priori set number of malfunctions. In order to validate the hypothesis, a test of compliance with equal distribution was used.

\section{Test results}

The analysis of unplanned costs of repairs was carried out for the database with malfunctions of vehicles included in a fleet of identical trams used by an operator in a large transport company. The data relate to the period of use of a fleet composed of $N=45$ trams with the mileage from 0 to $L=210$ thousand $\mathrm{km}$ for each vehicle and cover the warranty period that a manufacturer provided for the fleet operator. The mileage of 210 thousand $[\mathrm{km}]$ was divided into $k=7$ equal mileage periods of the length of 30 thousand $[\mathrm{km}]$ each. The statistical data relating to the distribution of the number of malfunctions and the total costs of repairs in individual mileage periods of the vehicles have been presented in Fig. 1

In order to test the hypothesis $H_{0}: \mu_{1}=\mu_{2}=\cdots=\mu_{7}$ assuming that in all seven mileage periods of the trams, the average costs of eliminating incidental malfunctions are equal, a classic ANOVA (analysis of variance) was used (see [1]) requiring fulfilling several assumptions. First, the following hypothesis was verified: $H_{0}: \sigma_{1}^{2}=\sigma_{2}^{2} \ldots=\sigma_{7}^{2}$ relating to homogeneity of variances of the total costs as opposed to the alternative hypothesis contradicting the previous one.

Table 2 presents the results of Bartlett, Hartley and Cochran tests on the homogeneity of variances for unit costs of repairs. The results obtained indicate non-homogeneity of the costs of repairs. This is due, among others, to several above-average costs of eliminating of malfunctions at the mileage from 150 thousand to 179 thousand $\mathrm{km}$ and factory activities related to malfunction elimination, e.g. conversions of collision equipment, change of the operating time of the emergency brake fluid tank pump or replacement of railings at first doors. 
Investigating the trends of average costs of corrective maintenance of public... Badanie tendencji przeciętnych kosztów nieplanowej obstugi pojazdów...

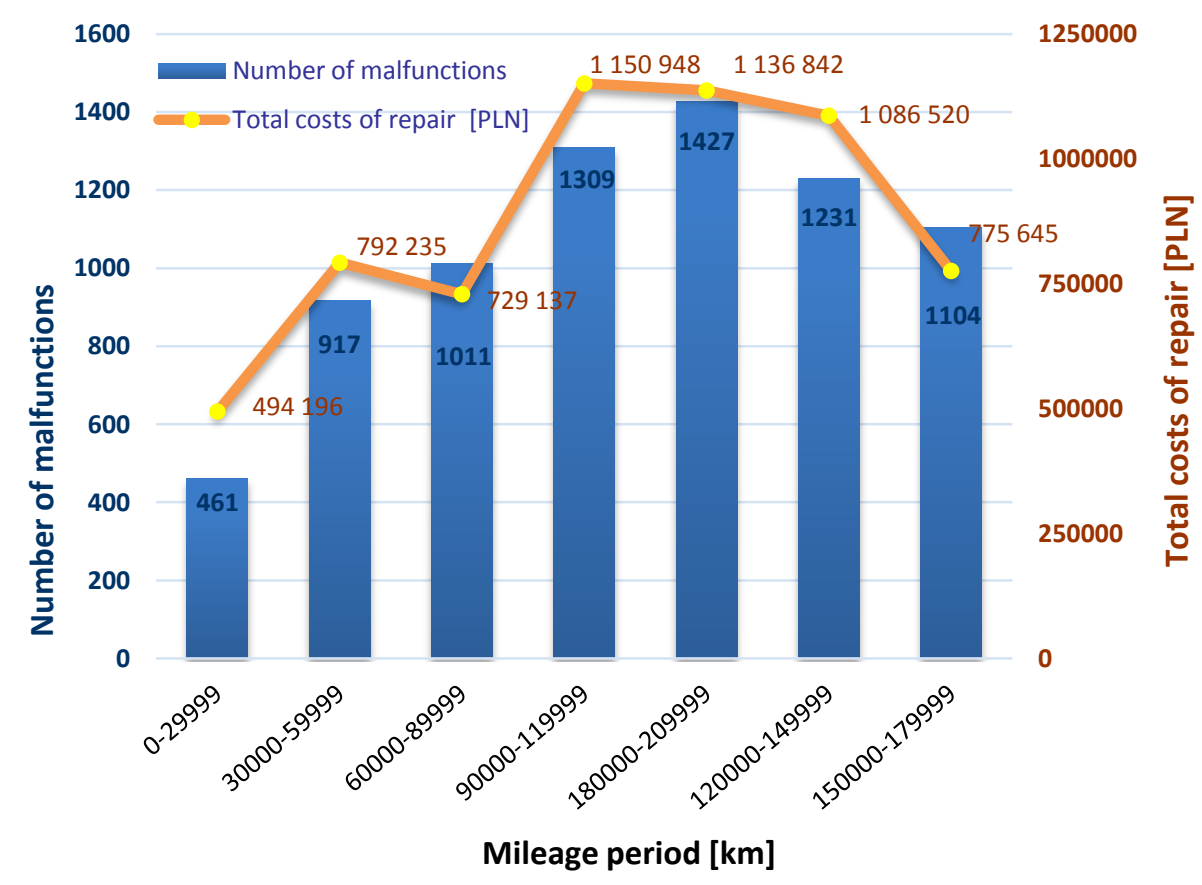

Fig. 1. Distribution of the number of malfunctions and the total costs of repair

Table 2. Results of Bartlett, Hartley and Cochran test

\begin{tabular}{|c|c|c|c|c|}
\hline $\begin{array}{c}\text { Hartley's } \\
\text { F-max. }\end{array}$ & $\begin{array}{c}\text { Cochran's } \\
\text { C }\end{array}$ & $\begin{array}{c}\text { Bartlett's } \\
\text { Chi-qu. }\end{array}$ & $\begin{array}{c}\text { Degrees } \\
\text { of } \\
\text { freedom }\end{array}$ & $\begin{array}{c}\text { Test } \\
\text { relevance }\end{array}$ \\
\hline 8.823736 & 0.529004 & 2698.29 & 6 & 0.00 \\
\hline
\end{tabular}

Additional Levene and Brown-Forsythe tests, resistant to deviating observations and deviations from normal distribution also confirmed the non-homogeneity of the variances of unit costs.

For the purpose of initial evaluation of normality of distribution of the level of unit costs in individual periods of use of the trams, Quantile to Quantile Q-Q plots, were used where theoretical quantities (estimated from the data) of costs distribution, i.e. $F^{-1}\left(\frac{i-0,5}{n}\right)$ were plotted on one (horizontal) axis, where $F$ denotes a cumulative distribution function of normal distribution and $i=1,2, \ldots, n$ denotes subsequent numbers of observations, while the quantiles of the distribution under comparison were plotted on the other (vertical) axis - therefore points $\left(F^{-1}\left(\frac{i-0,5}{n}\right), x_{(i)}\right)$ were overlain. The quantile charts showed high deviations of unit costs from normal distribution and allowed detecting the deviated observations. 
For the purpose of formal evaluation of normality of the distribution of costs for each period of use, Shapiro-Wilk test was applied.

The test was used for its fuller use of information contained in the data, compared to other commonly used tests of compliance and its greater power. In order to make the test complete, Kolmogorov-Lillieffors and Cramer-von Mises regularity tests were also performed. All the tests confirmed relevant incompliance of the data with normal distribution.

Despite the fact that the ANOVA assumptions were not fulfilled, based on the central limit theorem and due to extensive data, the relevance of differences was tested between the average costs of elimination of malfunctions in the seven selected mileage periods of the trams. The applied variance analysis test is relatively resistant to small deviations from normality of data (especially for large tests). The results of the ANOVA analysis conducted in order to compare the average costs of elimination of malfunctions in individual mileage periods of the trams included in the tested fleet have been shown in table 3. The determined effects connected with the division of the mileage into periods are not relevant because $p=0,52>0,05$. From the analysis of variance, it results that there are no significant differences between mileage periods of the trams in terms of average costs of elimination of unplanned malfunctions.

Table 3. Analysis of variance for unit costs of repairs

\begin{tabular}{|c|c|c|c|c|c|}
\hline $\begin{array}{c}\text { Variability } \\
\text { source }\end{array}$ & $\begin{array}{c}\text { Degrees of } \\
\text { freedom }\end{array}$ & Sum of squares & $\begin{array}{c}\text { Average } \\
\text { square }\end{array}$ & $\begin{array}{c}\text { Test } \\
\text { statistics }\end{array}$ & $\begin{array}{c}p \\
\text { value }\end{array}$ \\
\hline $\begin{array}{c}\text { Between } \\
\text { periods }\end{array}$ & 6 & 66027683 & 11004614 & 0.862009 & 0.521994 \\
\hline $\begin{array}{c}\text { Within } \\
\text { periods }\end{array}$ & 7453 & $9.514675 \mathrm{E}+10$ & 12766235 & & \\
\hline
\end{tabular}

The results of the presented ANOVA confirm 95\% confidence intervals of the average costs in individual mileage periods of mileages of the trams. The intervals have been shown in Fig. 2.

It results from the chart that the average costs of repairs for all mileage periods of the trams do not significantly differ on the assumed $95 \%$ level of confidence.

This is due to high variability of the unit costs of elimination of unplanned malfunctions, particularly in the first and sixth mileage period. This results in very wide confidence intervals.

The above is a consequence of very high or very low costs of elimination of malfunctions. In the first mileage period of the trams, expensive parts were renewed such as the event data recorder, passive brake caliper and pressure generator, whereas in the sixth mileage period, the most expensive subassemblies that were renewed were: the motor with a gearset, the automated ticket dispenser and the recorder module. On the other hand, the lowest costs both in the first and sixth mileage periods were generated by the renewals of washers, screws, gaskets and cotter pins. 
Investigating the trends of average costs of corrective maintenance of public... Badanie tendencji przeciętnych kosztów nieplanowej obstugi pojazdów...

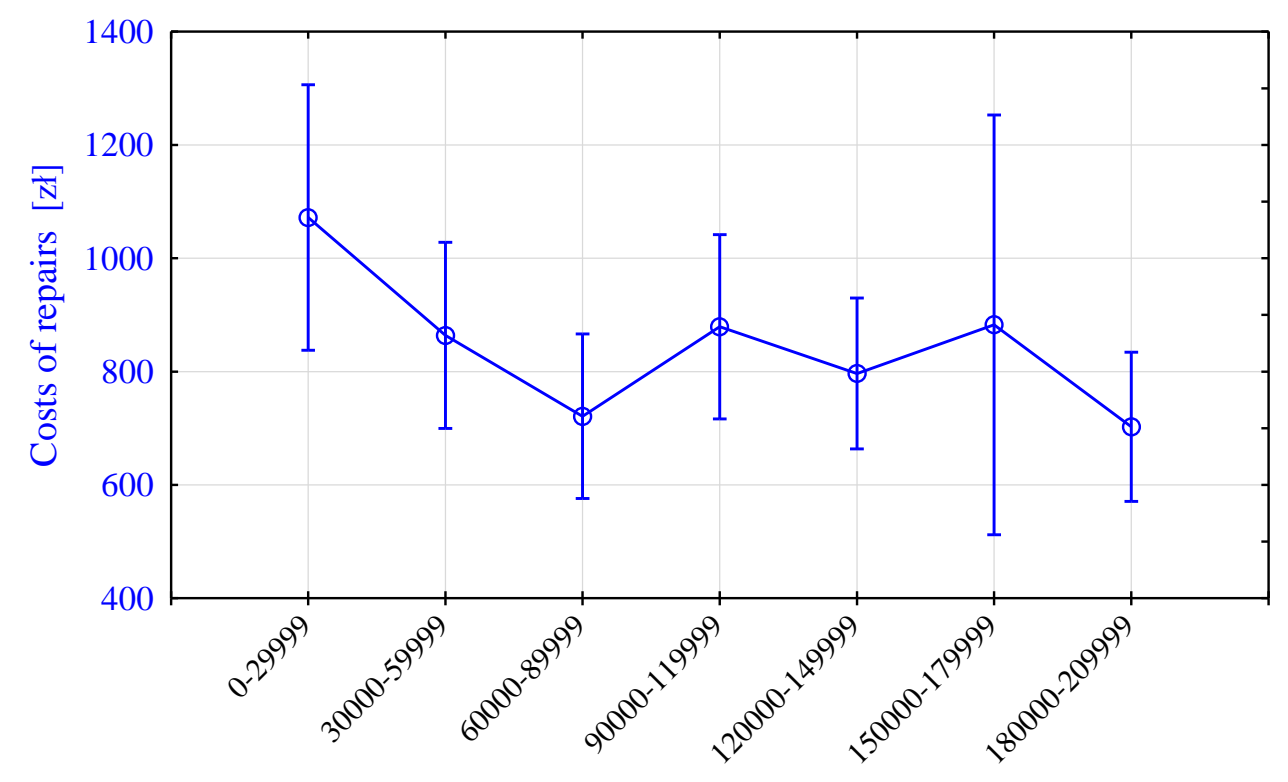

Mileage periods $[\mathrm{km}]$

Fig. 2. 95\% confidence intervals of the average costs of repairs in individual periods of use of the trams.

\section{Conclusions}

Today, the existence of public transport is determined by the Agile paradigm that assumes simultaneous existence of such life cycle stages as designing, production, operation and recycling. Design works are conducted on a daily basis and are aimed at constant adaptation of technical systems to the changing requirements and opportunities. The process of production implements these adaptations and converts them into operating characteristics. In the manufacturer-operator relation, a significant role is played by intense flows of information that can be controlled with the use of Big Data information technology. The tests on periodical trends of costs of corrective maintenance of public transport vehicles provide important information for the fleet suppliers. Keeping a full database of the operating data by a public transport operator is necessary for the manufacturer/supplier of a fleet of public transport vehicles, particularly in the period of extended warranty. This allows the manufacturer to plan the costs of warranty services and modernize the vehicles in order to reduce the number of malfunctions or even eliminate some of them permanently. In order to detect the relevant factors affecting the costs of elimination of malfunctions, further tests will be conducted considering not only the mileage but also other factors that may affect the differentiation of costs of elimination of unplanned vehicle malfunctions. 


\section{References}

[1] Andrzejczak K., Selech J.: Kwantylowa analiza kosztów eksploatacji floty pojazdów transportu masowego. Materiały Międzynarodowej Konferencji Naukowej Transport XXI wieku, 30 sierpnia - 2 września 2016 r. Arłamów.

[2] Andrzejczak K.: Charakterystyki niezawodnościowe złożonych systemów odnawialnych. Materiały Szkoły Niezawodności - Metody utrzymania gotowości systemów. PAN, Szczyrk 2008, 16-28.

[3] Andrzejczak K.: Metody prognozowania w modelowaniu eksploatacji środków transportu. Rozprawy $\mathrm{nr}$ 496. Wydawnictwo Politechniki Poznańskiej, Poznań 2013.

[4] Durairaj, S.K., Ong S.K., Nee A.Y.C., Tan R.B.H. Evaluation of Life Cycle Cost Analysis Methodologies. Corporate Environmental Strategy 2002; 9(1): 30-39, http://dx.doi.org/10.1016/S1066-7938(01)00141-5.

[5] Jun, H.K. \& Kim, J.H. 2007. Life cycle cost modelling for railway vehicle. Electrical Machines and Systems, ICEMS. International Conference on: IEEE. For rolling stocks. Computers \& Industrial Engineering, CIE 2009. International Conference on IEEE, pp 1189-1191.

[6] Młyńczak M. 2012. Metodyka badań eksploatacyjnych obiektów technicznych, Wrocław, Oficyna Wydawnicza Politechniki Wrocławskiej.

[7] Niziński S., Żółtowski B.: Informatyczne systemy zarządzania eksploatacją obiektów technicznych. MARKAR-B.Ż., Bydgoszcz 2001.

[8] PN-EN 60300-3-3: Zarządzanie niezawodnością. Część 3-3. Przewodnik zastosowań - Szacowanie kosztu cyklu życia. 2006.

[9] Projekt badawczy pt. „Wzrost efektywności funkcjonowania środków transportu publicznego $\mathrm{w}$ wyniku wdrożenia koncepcji LCC oraz RAMS zgodnych ze standardem IRIS opartych na zintegrowanym systemie informatycznym", Nr PBS3/B6/30/2015.

[10] Rymarz J., Niewczas A., Krzyżak A.: Comparison of operational availability of public city buses by analysis of variance. Maintenance and Reliability, vol. 18, No. 3, 2016, p. 373-378.

[11] Rymarz J., Niewczas A., Ocena niezawodności eksploatacyjnej autobusów komunikacji miejskiej, Problemy eksploatacyjne, nr 1/2012, s.79-85.

[12] Strauss P. Metoda analizy kosztów całkowitych pojazdu w okresie jego użytkowania. Technika Transportu Szynowego 5/2000.

[13] Nowakowski T: Problems of reliability modelling of multiple-phased systems. Eksploatacja i Niezawodnosc - Maintenance and Reliability 2011; 4: 79-84 
Investigating the trends of average costs of corrective maintenance of public... Badanie tendencji przeciętnych kosztów nieplanowej obstugi pojazdów...

[14] Szkoda M. Assessment of Reliability, Availability and Maintainability of Rail Gauge Change Systems, Eksploatacja i Niezawodność - Maintenance and Reliability, Vol. 16, no. 3, 422-432. 2014.

The presented test results have been delivered under a research project financed by National Cenetr for Research and Developmant, titled "Increase in the efficiency of functioning of public means of transport as a result of implementation of LCC and RAMS concepts in accordance with the IRIS standards based on integrated information technology system" (see [9]).

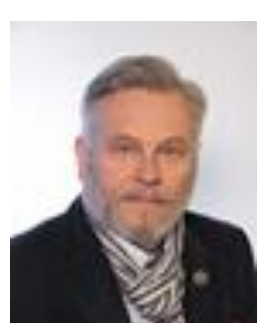

Karol Andrzejczak, PhD. Assistant Professor, graduated from Adam Mickiewicz University of Poznan majoring in Mathematics in 1980. Since his graduation, he has been affiliated with Institute of Mathematics of Poznan University of Technology. In 1987 he was awarded with the degree of PhD in Mathematical Sciences and in 2014 he was awarded with the degree of PhD habilitated in technical sciences in the field of transport. His academic interests focus on the theory of reliability and its applications, statistical methods and probabilistic modeling of readiness, operation and safety of transport systems and means of transport. He is a member of Polish Statistical Society, POLSPAR Polish Association of Measurements, Automatics and Robotics and the American Mathematical Society (Share: 50\%).

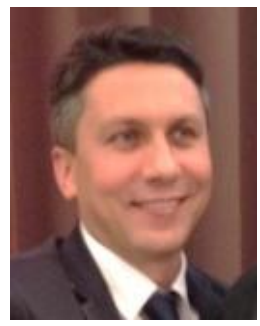

Jaroslaw Selech PhD Eng. graduated from Poznan University of Technology in 1999 majoring in mechanics and machine design. Since his graduation, he has been affiliated with Institute of Machines and Motor Vehicles of Poznan University of Technology. In 2005 he was awarded with the degree of PhD in technical sciences in the field of design and operation of machines. His academic interests focus on the methodology of research on operation of technical objects in the context of reliability forecasting and life cycle costs. He is a member of Polish Tribological Society, Association of Agricultural Engineering and Polish Scientific and Technical Operation Society. (Share: 50\%). 


\section{BADANIE TENDENCJI PRZECIĘTNYCH KOSZTÓW NIEPLANOWEJ OBSEUGI POJAZDÓW TRANSPORTU MASOWEGO}

\section{Wstęp}

Analiza kosztów eksploatacji środków transportu masowego jest zagadnieniem dość złożonym o czym świadczą liczne prace poświęcone tej tematyce (zob. [6], [8], [12], [7]). Głównym czynnikiem kosztotwórczym w przypadku floty pojazdów transportu masowego, poza jednorazowym kosztem zakupu, jest koszt ponoszony $\mathrm{w}$ fazie eksploatacji. Koszty generowane $\mathrm{w}$ tej fazie życia pojazdów, są szczegółowo analizowane zarówno z punktu widzenia dostawcy taboru, najczęściej producenta, jak również $\mathrm{z}$ punktu widzenia użytkownika, rozumianego jako operatora obsługującego transport masowy. Producent (dostawca) taboru zainteresowany jest kosztami fazy eksploatacji, gdyż ponosi on koszty gwarancji oraz kontraktów serwisowych zwłaszcza w początkowym okresie użytkowania pojazdów. Wiedza dotycząca kosztów eksploatacji pozwala dostawcy na zwiększenie możliwości ofertowych sprzedaży taboru, jak również może wpłynąć na możliwości negocjacyjne warunków sprzedaży i dodatkowe korzyści finansowe. Z kolei operator znając koszty eksploatacji jest w stanie lepiej je kontrolować, przez co zmniejsza ryzyko finansowe związane $\mathrm{z}$ planowo-zapobiegawczą i wymuszoną (nieplanową) obsługą pojazdów, ogranicza ryzyko zmniejszenia dostępności taboru oraz znacząco zmniejsza stopień zagrożenia związanego $z$ bezpieczeństwem realizacji zadań przewozowych. Ponadto znając prognozowane koszty eksploatacji już na etapie wyboru dostawcy taboru, ma on możliwość oceny efektywności alternatywnych rozwiązań ofertowych (zob. [4], [5]).

Projektanci, producenci i końcowi użytkownicy środków transportu starają się minimalizować możliwości pojawiania się różnego rodzaju zdarzeń niepożądanych w czasie ich użytkowania. Aby zminimalizować koszty usuwania uszkodzeń projektant musi wiedzieć, dlaczego i jakie zdarzenia niepożądane mogą wystąpić w czasie użytkowania obiektu technicznego. Pozwoli to na niedopuszczanie do wystąpienia takich zdarzeń lub uodpornienie konstrukcji obiektu na skutki ich wystąpienia poprzez projektowanie różnego rodzaju układów nadmiarowych i organizację działań prewencyjnych obniżających koszty eksploatacji środków transportu (zob. [2], [6], [14]). Mimo, że już w fazie projektowania uwzględniane są wszelkie wymagania dotyczące m. in. założonej gotowości operacyjnej środka transportu, to nieuniknione są losowe uszkodzenia środków transportu w czasie ich użytkowania, które generują nieplanowe koszty eksploatacji. Aby zaprojektować i zbudować złożony obiekt techniczny spełniający wymagania dotyczące jego energochłonności, kosztochłonności, ekologii, bezpieczeństwa, gotowości i funkcjonalności niezbędna jest rozległa wiedza szczegółowa dotycząca m.in. prognozowania jak często i kiedy wystąpią zdarzenia niepożądane w czasie jego użytkowania (zob. [3] [11], [13],). 
Investigating the trends of average costs of corrective maintenance of public... Badanie tendencji przeciętnych kosztów nieplanowej obstugi pojazdów...

W niniejszej publikacji autorzy przedstawiają wyniki badań dotyczących nieplanowych kosztów usuwania uszkodzeń w okresie gwarancyjnym, przeprowadzonych na podstawie danych dotyczących floty tramwajów eksploatowanych przez miejskie przedsiębiorstwo komunikacyjne.

Opracowanie składa się z pięciu części oraz wykazu literatury. W części 2 uściślono rozważane zagadnienie kosztochłonności eksploatacji dla floty pojazdów transportu masowego. W części 3 przedstawiono problem badawczy i metodę badawczą. W części 4 tej pracy na przykładzie floty pojazdów transportu masowego przedstawiono wyniki badań. Praca kończy podsumowaniem oraz wykazem literatury.

\section{Uściślenie zagadnienia kosztochłonności}

$\mathrm{Na}$ bezpośrednie koszty fazy eksploatacji floty pojazdów składają się koszty użytkowania, czyli koszty generowane w trakcie działania pojazdu (np. koszty energii, materiałów eksploatacyjnych, personelu obsługującego), koszty obsługiwania planowego (np. koszty wykonania obsług profilaktycznych, tj. przeglądów i napraw, części zamiennych, regulacji, konserwacji) oraz koszty obsługiwania nieplanowego, wymuszonego zdarzeniami losowymi, obejmujące m.in. koszt przywrócenia pojazdu do zdatności (np. regulacje śrub, mocowań i połączeń elektrycznych, zmiana ustawień i resetowanie działania urządzeń elektronicznych, wymiana pękniętej szyby, naprawa powypadkowa, koszty kar spowodowane niegotowością pojazdu, itp.) lub wykrytego w trakcie obsługi planowej jako działanie zapobiegawcze.

W celu przeprowadzenia szczegółowej analizy kosztów fazy eksploatacji floty pojazdów transportu masowego, $\mathrm{z}$ ewentualną próbą prognozowania rodzajów kosztów, muszą być rejestrowane wszystkie zdarzenia, które generują koszt. Tworzenie bazy danych dotyczącej szeroko rozumianej uszkadzalności, uwzględniającej wszelkie koszty eksploatacji floty pojazdów transportu masowego, należy do podstawowych działań w procesie planowania kosztów, serwisowania i remontów (zob. [6]).

Bazę danych dotyczącą uszkadzalności oraz kosztów eksploatacji i serwisowania można uzyskać z dokumentacji obsługi floty pojazdów transportu masowego, jakimi są np. tramwaje użytkowane w dużym przedsiębiorstwie komunikacyjnym. $\mathrm{Na}$ podstawie takiej bazy danych można dokonać identyfikacji najbardziej kosztotwórczych części (zob. [1]), oszacować koszty jednostkowe oraz wyznaczyć charakterystyki niezawodnościowe niezbędne w planowaniu dalszej eksploatacji floty.

\section{Problem badawczy i metoda badawcza}

Problem badawczy dotyczy analizy porównawczej przeciętnych kosztów usuwania losowych uszkodzeń oraz ich liczby, w wyróżnionych okresach użytkowania określonej floty jednorodnych pojazdów transportu masowego. Ze względu na możliwość wprowadzania do eksploatacji w różnym czasie nowych pojazdów wchodzących w skład badanej floty, wyróżnione okresy ich użytkowania wyrażone są $\mathrm{w}$ przebiegach $\mathrm{w}[\mathrm{km}]$. 
Odmierzanie okresów użytkowania pojazdów w przebiegach pozwala lepiej analizować koszty usuwania uszkodzeń i momenty ich wystąpienia przy zróżnicowanej intensywności użytkowania pojazdów.

W niniejszej pracy analizę kosztów ograniczamy do tych kosztów, które nie są uwzględniane w przeglądach planowych. Jest to więc analiza kosztów wymiany tych części, które uszkadzają się w losowych chwilach użytkowania środków transportu zwykle w okresach między przeglądami. Analiza kosztów jest przeprowadzona na podstawie odpowiednio przygotowanej bazy danych eksploatacyjnych dotyczących badanej floty pojazdów. Informacje zawarte w bazie danych wyznaczają zakres możliwych badań eksploatacyjnych. Podstawowe dane źródłowej bazy danych eksploatacyjnych zawierają informacje dotyczące m.in.:

- liczby porządkowej wymienianej części zgodnej z chronologią czasową,

- oznaczenia pojazdu,

- indeksu części zamiennej,

- grupy konstrukcyjnej,

- przebiegu pojazdu przy jakim wystąpiło uszkodzenie,

- nazwy wymienianej części,

- daty naprawy,

- kosztu części,

- koszt robocizny.

Przykładowe rekordy zaprezentowano w tablicyl.

Tabela 1. Struktura źródtowej bazy danych

\begin{tabular}{|c|c|c|c|c|c|c|c|}
\hline Część & Indeks części & $\begin{array}{c}\text { Grupa } \\
\text { konstr. }\end{array}$ & $\begin{array}{c}\text { Przebieg } \\
{[\mathbf{k m}]}\end{array}$ & $\begin{array}{c}\text { Nazwa } \\
\text { części }\end{array}$ & $\begin{array}{c}\text { Data } \\
\text { naprawy }\end{array}$ & $\begin{array}{c}\text { Koszt } \\
\text { części } \\
{[\text { [PLN] }}\end{array}$ & $\begin{array}{c}\text { Koszt } \\
\text { RBG } \\
\text { [PLN] }\end{array}$ \\
\hline 1. & $0004-010-219$ & 8 & 196006 & $\begin{array}{c}\text { Czujnik } \\
\text { ciśnienia }\end{array}$ & $2015-06-15$ & 488,67 & 330,00 \\
\hline 2. & $3400-003-454$ & 24 & 125588 & $\begin{array}{c}\text { Sterownik } \\
\text { drzwi }\end{array}$ & $2013-04-24$ & 29333,88 & 660,00 \\
\hline 3. & $3400-003-574$ & 8 & 196006 & $\begin{array}{c}\text { Amortyzator } \\
\text { poziomy }\end{array}$ & $2013-10-16$ & 1286,00 & 220,00 \\
\hline
\end{tabular}

W przeprowadzonych badaniach istotności różnic przeciętnych kosztów usuwania losowych uszkodzeń wykorzystane są dane dotyczące przebiegów pojazdów, przy których wystąpiło uszkodzenie oraz dane dotyczące indeksów części, kosztów części i kosztów robocizny związanych z usunięciami poszczególnych uszkodzeń. W prezentowanych badaniach rozpatrywano łączne koszty usuwania uszkodzeń, tj. koszty części oraz koszty roboczogodzin związanych z wymianą tych części.

Niech $B_{(0 ; L)}$ oznacza bazę danych eksploatacyjnych za okres od wprowadzenia poszczególnych pojazdów do użytkowania aż do osiągniecia przebiegu $L[\mathrm{~km}]$ przez wszystkie pojazdy floty. 
Investigating the trends of average costs of corrective maintenance of public... Badanie tendencji przeciętnych kosztów nieplanowej obstugi pojazdów...

Korzystając z bazy danych $B_{(0 ; L)}$ o kosztach usuwania losowych uszkodzeń pojazdów floty, które uzyskały przebieg co najmniej $L[\mathrm{~km}]$, badana jest istotność różnic przeciętnych kosztów usuwania uszkodzeń w wyróżnionych $k$ okresach przebiegu pojazdów.

W tym celu przebieg $L$ wyrażony w [km] dla każdego pojazdu floty jest podzielony na $k$ równych okresów przebiegu, tj. dokonujemy podziału okresu $L$ na przedziały

$$
\left[0 ; \frac{1}{k} L\right),\left[\frac{1}{k} L ; \frac{2}{k} L\right), \ldots,\left[\frac{k-1}{k} L ; L\right)
$$

W konsekwencji z bazy danych $B_{(0 ; L)}$ dotyczącej floty $N$ pojazdów tworzymy $k$ podbaz danych $B_{1}, B_{2}, \ldots, B_{k}$ związanych z wyróżnionymi okresami użytkowania pojazdów. Dane te są wykorzystane do sprawdzenia hipotezy, że są istotne różnice przeciętnych kosztów usuwania uszkodzeń w wyróżnionych okresach użytkowania pojazdów. W tym celu sprawdzana jest hipoteza zerowa

$$
H_{0}: \mu_{1}=\mu_{2}=\cdots=\mu_{k}
$$

gdzie $\mu_{i}$ jest przeciętnym poziomem kosztów usuwania losowych uszkodzeń pojazdów w $i$-tym okresie ich eksploatacji. Odrzucenie tak postawionej hipotezy zerowej oznacza występowanie pewnych trendów. Zanim przedstawione zostanie rozstrzygnięcie tego problemu wcześniej przedstawimy wynik weryfikacji hipotezy: losowa liczba zarejestrowanych uszkodzeń przypadających na jeden pojazd floty nie różni się istotnie dla poszczególnych okresów eksploatacji floty. Hipoteza zerowa przyjmuje postać:

$$
H_{0}: u_{1}=u_{2}=\cdots=u_{k}=u_{0}
$$

gdzie $u_{i}$ jest przeciętną liczbą uszkodzeń przypadających na jeden pojazd floty w $i$-tym okresie użytkowania $(i=1,2, \ldots, k)$, natomiast $u_{0}$ jest a priori zadaną liczbą uszkodzeń. Do weryfikacji tej hipotezy zastosowano test zgodności z rozkładem równomiernym.

\section{Wyniki badań}

Analizę kosztów napraw nieplanowych przeprowadzono dla bazy danych o uszkodzeniach pojazdów z floty jednorodnych tramwajów użytkowanych przez operatora w dużym przedsiębiorstwie komunikacyjnym. Dane dotyczą czasu eksploatacji floty $N=45$ tramwajów o przebiegu od 0 do $L=210$ tys. km przez każdy pojazd i obejmują okres gwarancyjny, jaki producent zapewnił operatorowi floty. Przebieg 210 tys. [km] został podzielony na $k=7$ równych okresów przebiegu o długości po 30 tys. [km] każdy. Dane syntetyczne dotyczące rozkładu liczby usterek i sumarycznych kosztów napraw w poszczególnych okresach przebiegu pojazdów zestawiono na rys. 1 . 
Sprawdzenie hipotezy, że we wszystkich fazach liczba losowych uszkodzeń na 1 pojazd wynosi 25 daje statystykę $\chi^{2}$ Pearsona o wartości 12,54, natomiast kwantyl górny wyznaczający wartość krytyczną wynosi $\chi_{0,95 ; 6}^{2}=12,59$. Tak więc na poziomie istotności $95 \%$ jesteśmy na granicy odrzucenia hipotezy, że liczby losowych uszkodzeń nie różnią się istotnie dla poszczególnych okresów użytkowania tramwajów.

Pomijając pierwszą fazę, która zdecydowanie odbiega od pozostałych co do liczby uszkodzeń statystyka $\chi^{2}$ Pearsona daje wartość 3,82961, natomiast wartość krytyczna wynosi $\chi_{0,95 ; 5}^{2}=11,07$, co już zdecydowanie nie daje podstaw do odrzucenia hipotezy o liczbie uszkodzeń 25 na pojazd, w każdym okresie jego użytkowania począwszy od przebiegu 30 tys. [km].

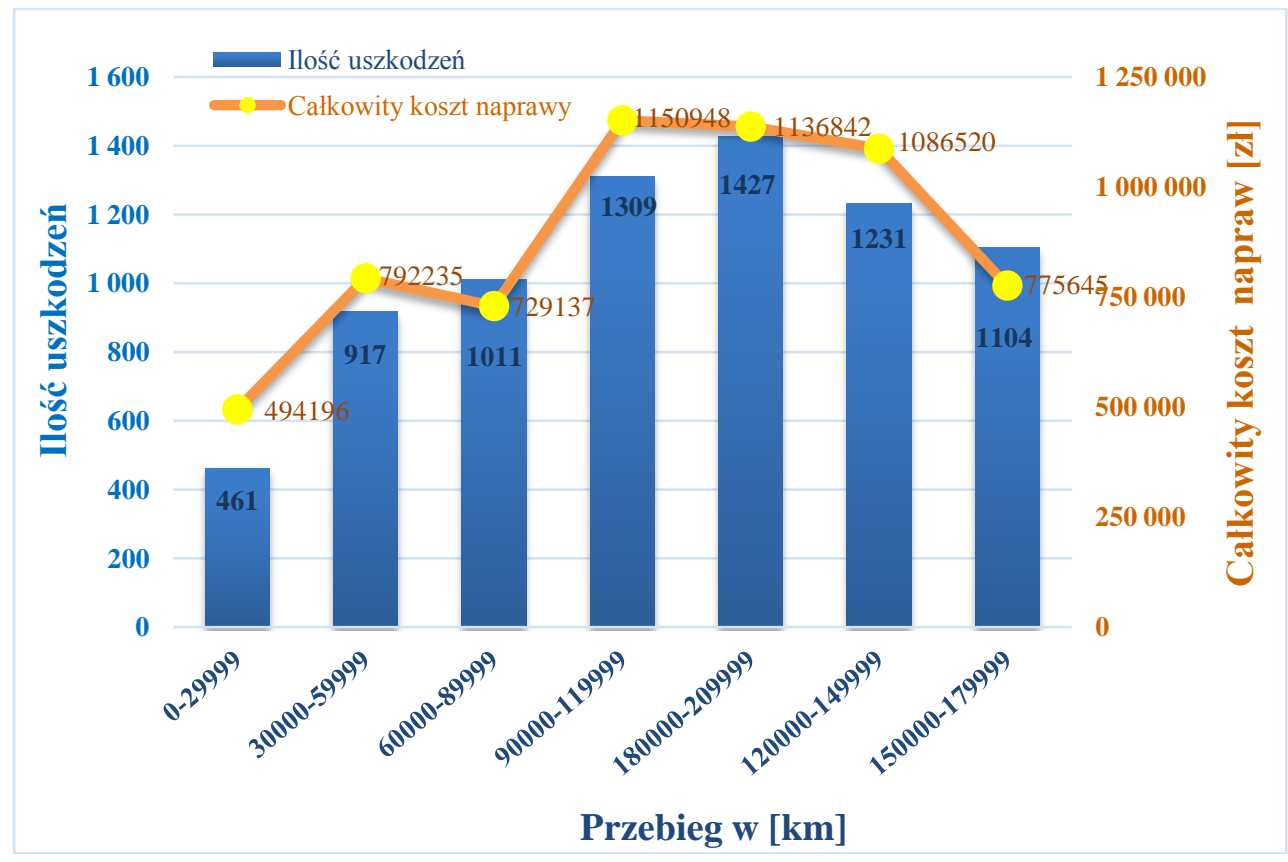

Rys. 1. Rozktad liczby uszkodzeń i sumarycznych kosztów napraw [źródto: opracowanie własne]

Do zweryfikowania hipotezy $H_{0}: \mu_{1}=\mu_{2}=\cdots=\mu_{7}$, że we wszystkich siedmiu okresach użytkowania tramwajów przeciętne koszty usuwania ich losowych uszkodzeń są równe zastosowano klasyczną metodę analizy wariancji ANOVA (zob. [1]), która wymaga spełnienia kilku założeń. Przede wszystkim zweryfikowano hipotezę: $H_{0}: \sigma_{1}^{2}=\sigma_{2}^{2} \ldots=\sigma_{7}^{2}$ o jednorodności wariancji łącznych kosztów, przeciw hipotezie alternatywnej będącej jej zaprzeczeniem. 
Investigating the trends of average costs of corrective maintenance of public... Badanie tendencji przeciętnych kosztów nieplanowej obstugi pojazdów...

W tabeli 2 przedstawiono wyniki testów jednorodności wariancji Bartletta, Hartleya i Cochrana dla jednostkowych kosztów napraw. Otrzymane wyniki wskazują na niejednorodność wariancji kosztów. Spowodowane to jest m.in. kilkoma ponadprzeciętnymi kosztami usuwania uszkodzeń, zwłaszcza $\mathrm{w}$ fazie przebiegu od 150 tys. do 179 tys. km oraz fabryczną akcją usuwania uszkodzeń np. przebudowa aparatów zderzeniowych, zmiana czasu pracy pompy hydrogeretu awaryjnego, wymiana poręczy przy pierwszych drzwiach.

Tabela 2. Wyniki testu Bartletta, Hartleya i Cochrana [opracowanie wtasne]

\begin{tabular}{|c|c|c|c|c|}
\hline Hartleya F-maks & Cochrana C & Bartlett Chi-kw. & $\begin{array}{c}\text { Stopnie } \\
\text { swobody }\end{array}$ & $\begin{array}{c}\text { Istotność } \\
\text { testu }\end{array}$ \\
\hline 8,823736 & 0,529004 & 2698,29 & 6 & 0,00 \\
\hline
\end{tabular}

Dodatkowo przeprowadzone testy Levene'a i Browna-Forsythe'a odporne na obserwacje odstające i odstępstwa od rozkładu normalnego również potwierdziły niejednorodność wariancji jednostkowych kosztów.

Do wstępnej oceny normalności rozkładu poziomu jednostkowych kosztów $\mathrm{w}$ poszczególnych okresach użytkowania tramwajów zastosowano wykresy kwantylowe Q-Q (ang. Quantile to Quantile Q-Q plot), w których na jednej osi (poziomej) umieszczane są kwantyle teoretyczne (estymowane $\mathrm{z}$ danych) rozkładu kosztów, tj. $F^{-1}\left(\frac{i-0,5}{n}\right)$, gdzie $F$ oznacza dystrybuantę rozkładu normalnego, a $i=1,2, \ldots, n$ kolejne numery obserwacji, a na drugiej osi (pionowej) kwantyle porównywanego rozkładu - naniesiono więc punkty $\left(F^{-1}\left(\frac{i-0,5}{n}\right), x_{(i)}\right)$. Wykresy kwantylowe uwidoczniły duże odstępstwa kosztów jednostkowych od rozkładu normalnego i pozwoliły wykryć obserwacje odstające.

Do formalnego zbadania normalności rozkładu kosztów dla każdego okresu eksploatacji zastosowany został test $W$ Shapiro-Wilka (ang. Shapiro-Wilk test). Test ten został użyty ze względu na jego pełniejsze niż powszechnie stosowane testy zgodności, wykorzystanie informacji zawartej w danych oraz ze względu na jego dużą moc. Dla kompletności badania normalności przeprowadzone zostały również testy normalności Kołmogorowa-Lilliefforsa oraz Cramera-von Misesa. Wszystkie testy potwierdziły istotną niezgodność danych z rozkładem normalnym. Pomimo, że nie są spełnione założenia ANOVA, to na podstawie centralnego twierdzenia granicznego, ze względu na dużą liczbę danych, zbadano istotność różnic przeciętnych kosztów usuwania uszkodzeń, w wyróżnionych siedmiu okresach użytkowania tramwajów. Zastosowany test analizy wariancji jest stosunkowo odporny na nieduże odchylenia od normalności danych (zwłaszcza dla dużych prób). 
Wyniki przeprowadzonej analizy ANOVA dla porównania przeciętnych kosztów usuwania uszkodzeń w poszczególnych okresach przebiegu tramwajów badanej ich floty są zestawione $\mathrm{w}$ tabeli 3 . Wyznaczone efekty związane $\mathrm{z}$ podziałem przebiegu na okresy nie są istotne, gdyż $p=0,52>0,05$.

$\mathrm{Z}$ analizy wariancji wynika, że nie ma istotnych różnic między okresami użytkowania tramwajów $\mathrm{w}$ przeciętnych kosztach usuwania nieplanowych uszkodzeń.

Tabela 3. Analiza wariancji jednostkowych kosztów napraw [opracowanie własne]

\begin{tabular}{|c|c|c|c|c|c|}
\hline $\begin{array}{c}\text { Źródło } \\
\text { zmienności }\end{array}$ & $\begin{array}{c}\text { Stopnie } \\
\text { swobody }\end{array}$ & $\begin{array}{c}\text { Suma } \\
\text { kwadratów }\end{array}$ & $\begin{array}{c}\text { Sredni } \\
\text { kwadrat }\end{array}$ & $\begin{array}{c}\text { Statystyka } \\
\text { testowa }\end{array}$ & $\begin{array}{c}\text { Istotność } \\
\text { testu }\end{array}$ \\
\hline Między okresami & 6 & 66027683 & 11004614 & 0,862009 & 0,521994 \\
\hline $\begin{array}{c}\text { Wewnątrz } \\
\text { okresów }\end{array}$ & 7453 & $9,514675 \mathrm{E}+10$ & 12766235 & & \\
\hline
\end{tabular}

Wyniki przedstawionej analizy wariancji potwierdzają 95\% przedziały ufności przeciętnych kosztów, w poszczególnych okresach użytkowania tramwajów. Przedziały te zostały przedstawione graficznie na rysunku 2.

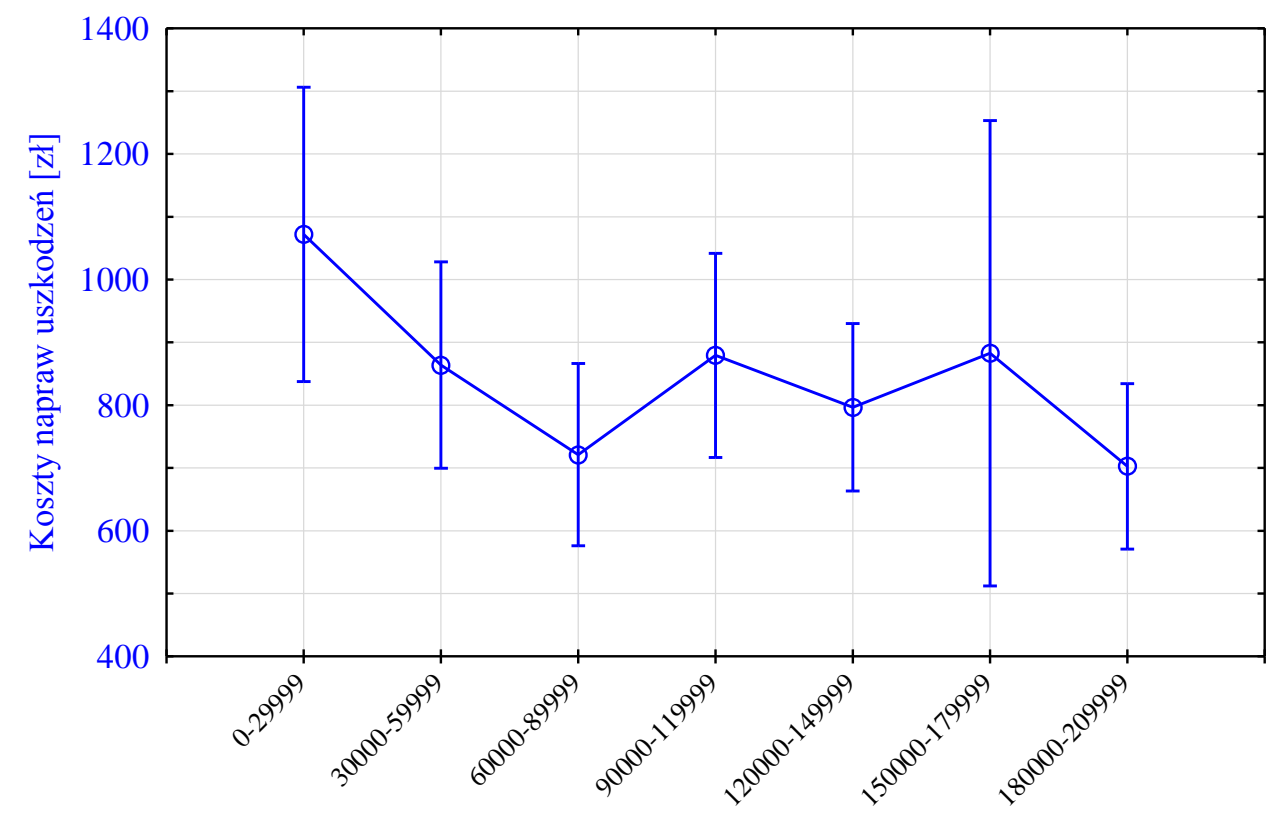

Okresy przebiegu $[\mathrm{km}]$

Rys. 2. 95\% przedzialy ufności przeciętnych kosztów napraw w poszczególnych okresach użytkowania tramwajów. 
Investigating the trends of average costs of corrective maintenance of public... Badanie tendencji przeciętnych kosztów nieplanowej obstugi pojazdów...

Z wykresu widać, że przeciętne koszty napraw dla wszystkich okresów przebiegu tramwajów nie różnią się istotnie na przyjętym $95 \%$ poziomie ufności. Spowodowane to jest dużą zmiennością jednostkowych kosztów usuwania nieplanowych uszkodzeń, zwłaszcza w pierwszej i szóstej fazie przebiegu. Efektem tego są bardzo szerokie przedziały ufności.

\section{Podsumowanie}

Współcześnie istnienie środków transportu masowego wyznacza paradygmat Agile, który zakłada jednoczesne istnienie takich faz ich życia jak: projektowanie, wytwarzanie, eksploatację i recykling. Prace projektowe prowadzone są cały czas i mają na celu ciągłe adaptacje systemów technicznych do zmieniających się wymagań i możliwości. Proces wytwarzania wdraża te adaptacje i przekłada je na cechy eksploatacyjne. W układzie producent - operator istotną rolę odgrywają intensywne przepływy informacyjne możliwe do opanowania $\mathrm{w}$ technologii informatycznej typu Big Data. Przeprowadzone badania tendencji okresowych kosztów nieplanowej obsługi pojazdów transportu publicznego dostarczają ważnych informacji dla dostawcy taboru. Prowadzenie pełnej bazy danych eksploatacyjnych przez operatora publicznego transportu zbiorowego jest niezbędne dla producenta/dostawcy floty środków transportu masowego zwłaszcza w okresie przedłużonej gwarancji.

Pozwala to producentowi planować koszty usług gwarancyjnych oraz dokonywać takich modernizacji środków transportu, które zmniejszą liczbę uszkodzeń lub wręcz wyeliminują pewne typy uszkodzeń. W celu wykrycia istotnych czynników wpływających na koszty usuwania uszkodzeń prowadzone będą dalsze badania uwzględniające nie tylko przebieg, ale inne czynniki mogące mieć wpływ na zróżnicowanie kosztów usuwania nieplanowych uszkodzeń części.

\section{Literatura}

[1] Andrzejczak K., Selech J.: Kwantylowa analiza kosztów eksploatacji floty pojazdów transportu masowego. Materiały Międzynarodowej Konferencji Naukowej Transport XXI wieku, 30 sierpnia - 2 września 2016 r. Arłamów.

[2] Andrzejczak K.: Charakterystyki niezawodnościowe złożonych systemów odnawialnych. Materiały Szkoły Niezawodności - Metody utrzymania gotowości systemów. PAN, Szczyrk 2008, 16-28.

[3] Andrzejczak K.: Metody prognozowania w modelowaniu eksploatacji środków transportu. Rozprawy $\mathrm{nr}$ 496. Wydawnictwo Politechniki Poznańskiej, Poznań 2013. 
[4] Durairaj, S.K., Ong S.K., Nee A.Y.C., Tan R.B.H. Evaluation of Life Cycle Cost Analysis Methodologies. Corporate Environmental Strategy 2002; 9(1): 30-39, http://dx.doi.org/10.1016/S1066-7938(01)00141-5.

[5] Jun, H.K. \& Kim, J.H. 2007. Life cycle cost modelling for railway vehicle. Electrical Machines and Systems, ICEMS. International Conference on: IEEE. For rolling stocks. Computers \& Industrial Engineering, CIE 2009. International Conference on IEEE, pp 1189-1191.

[6] Młyńczak M. 2012. Metodyka badań eksploatacyjnych obiektów technicznych, Wrocław, Oficyna Wydawnicza Politechniki Wrocławskiej.

[7] Niziński S., Żółtowski B.: Informatyczne systemy zarządzania eksploatacją obiektów technicznych. MARKAR-B.Ż., Bydgoszcz 2001.

[8] PN-EN 60300-3-3: Zarządzanie niezawodnością. Część 3-3. Przewodnik zastosowań - Szacowanie kosztu cyklu życia. 2006.

[9] Projekt badawczy pt. „Wzrost efektywności funkcjonowania środków transportu publicznego $\mathrm{w}$ wyniku wdrożenia koncepcji LCC oraz RAMS zgodnych ze standardem IRIS opartych na zintegrowanym systemie informatycznym", Nr PBS3/B6/30/2015.

[10] Rymarz J., Niewczas A., Krzyżak A.: Comparison of operational availability of public city buses by analysis of variance. Maintenance and Reliability, vol. 18, No. 3, 2016, p. 373-378.

[11] Rymarz J., Niewczas A., Ocena niezawodności eksploatacyjnej autobusów komunikacji miejskiej, Problemy eksploatacyjne, nr 1/2012, s.79-85.

[12] Strauss P. Metoda analizy kosztów całkowitych pojazdu w okresie jego użytkowania. Technika Transportu Szynowego 5/2000.

[13] Nowakowski T: Problems of reliability modelling of multiple-phased systems. Eksploatacja i Niezawodnosc - Maintenance and Reliability 2011; 4: 79-84

[14] Szkoda M. Assessment of Reliability, Availability and Maintainability of Rail Gauge Change Systems, Eksploatacja i Niezawodność - Maintenance and Reliability, Vol. 16, no. 3, 422-432. 2014. 
Investigating the trends of average costs of corrective maintenance of public... Badanie tendencji przeciętnych kosztów nieplanowej obstugi pojazdów...

Prezentowane wyniki badań zostaly wykonane $w$ ramach projektu badawczego finansowanego ze środków Narodowego Centrum Badań i Rozwoju pt. „Wzrost efektywności funkcjonowania środków transportu publicznego w wyniku wdrożenia koncepcji LCC oraz RAMS zgodnych ze standardem IRIS opartych na zintegrowanym systemie informatycznym" (zob. [9]).

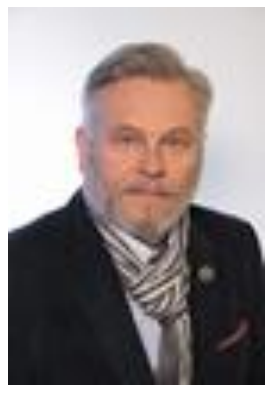

Dr hab. Karol Andrzejczak ukończyt studia na kierunku matematyka w 1980 roku na Uniwersytecie im. Adama Mickiewicza $w$ Poznaniu. Od ukończenia studiów pracuje w Instytucie Matematyki Politechniki Poznańskiej. W 1987 roku otrzymat stopien doktora nauk matematycznych, a w 2014 roku doktora habilitowanego nauk technicznych $w$ dyscyplinie transport. Jego zainteresowania naukowe dotycza teorii niezawodności $i$ jej zastosowań, metod statystycznych i probabilistycznego modelowania gotowości, eksploatacji oraz bezpieczeństwa systemów transportowych $i$ środków transportu. Jest czlonkiem Polskiego Towarzystwa Statystycznego, Polskiego Stowarzyszenia Pomiarów, Automatyki $i$ Robotyki POLSPAR oraz Amerykańskiego Towarzystwa Matematycznego. (Udziat 50\%).

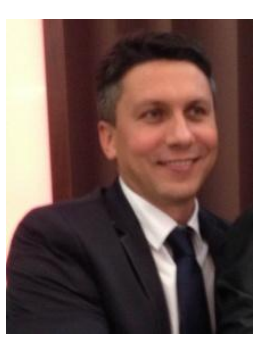

Dr inż. Jarostaw Selech ukończyt studia na kierunku mechanika i budowa maszyn w 1999 roku na Politechnice Poznańskiej. Od ukończenia studiów pracuje w Instytucie Maszyn Roboczych i Pojazdów Samochodowych Politechniki Poznańskiej. W 2005 otrzymat stopień naukowy doktora nauk technicznych $w$ dyscyplinie budowa $i$ eksploatacja maszyn. Swoje zainteresowania naukowe koncentruje wokót metodyki badań eksploatacyjnych obiektów technicznych $w$ aspekcie prognozowania niezawodności i kosztów cyklu życia. Jest członkiem Polskiego Towarzystwa Tribologicznego, Polskiego Towarzystwa Inżynierii Rolniczej oraz Polskiego Naukowo-Technicznego Towarzystwa Eksploatacyjnego. (Udziat 50\%). 